\title{
Effect of Moringa oleifera leaf meal on finisher pig growth performance, meat quality, shelf life and fatty acid composition of pork
}

\author{
F.E. Mukumbo ${ }^{1}$, V. Maphosa ${ }^{1}$, A. Hugo ${ }^{2}$, T.T. Nkukwana ${ }^{1}$, T.P. Mabusela ${ }^{1}$ \& V. Muchenje ${ }^{1 \#}$ \\ ${ }^{1}$ Department of Livestock and Pasture Science, Faculty of Science and Agriculture, \\ University of Fort Hare, P/Bag X1314, Alice 5700, South Africa \\ ${ }^{2}$ Department of Microbial Biochemical and Food Biotechnology, University of the Free State, \\ P.O. Box 339, Bloemfontein, 9300, South Africa
}

(Received 15 September 2014; Accepted 15 November 2014; First published online 12 December 2014)

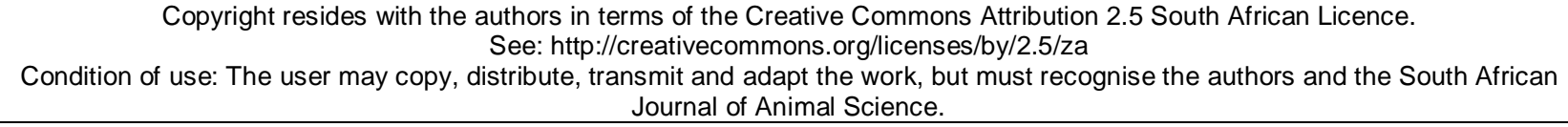

\begin{abstract}
The effect of dietary inclusion of Moringa oleifera leaf meal (MOLM) on the feed conversion ratio (FCR) of finisher pigs, physico-chemical meat quality, fatty acid (FA) composition and shelf life of pork was investigated. A six-week feeding trial was conducted with 24 Large White $x$ Landrace gilts aged 14 weeks. Each pig was housed individually and randomly allocated to one of four dietary treatments, containing $0 \%$, $2.5 \%, 5 \%$ or $7.5 \%$ MOLM, with six replicates per treatment. Feed intake was measured daily, pig liveweight was measured weekly, and average daily gains (ADGs) and FCR were calculated. Pigs were slaughtered at 20 weeks old and measurements of backfat thickness, $\mathrm{pH}_{45 \mathrm{~min}}$ and $\mathrm{pH}_{24 \mathrm{~h}}$ were taken. Muscularis longissimus thoracis et lumborum muscle samples from each carcass were analysed for physico-chemical quality. Muscle, subcutaneous fat and feed samples were analysed for FA composition and health lipid indices of atherogenicity (AI) and thrombogenicity (IT) were calculated. A 10-day shelf-life study was conducted, during which instrumental and sensory meat colour and odour were assessed. Pigs fed $7.5 \%$ MOLM had significantly higher average daily feed intakes (3.56 kg/day) than pigs fed $0 \%, 2.5 \%$ and $5 \%$ MOLM (3.05, 3.14 and $3.07 \mathrm{~kg} /$ day, respectively). The FCR of pigs fed $0 \%, 2.5 \%$ and $5 \%$ MOLM did not differ significantly (3.34, 3.44 and 3.22, respectively). However, the FCR of pigs fed $7.5 \%$ MOLM was significantly poorer (3.78). No significant differences were observed for carcass and physico-chemical quality traits. MOLM inclusion improved shelf life, as meat samples from MOLM-fed pigs exhibited significantly prolonged acceptability of colour and odour during 10 days of refrigerated storage. Although the $n-6: n-3$ FA ratios of the dietary treatments containing MOLM were significantly improved $(\mathrm{T} 1=35.45, \mathrm{~T} 2=22.08, \mathrm{~T} 3=14.24, \mathrm{~T} 4$ $=15.90$ ), no significant differences were observed for this ratio in the fat composition of the meat or subcutaneous fat samples between treatments. A significant reduction in intramuscular fat and stearic acid content was observed with increasing levels of MOLM. However, all other FA profiles, ratios and health lipid indices did not differ significantly across treatments. In conclusion, up to $5 \%$ MOLM may be included in finisher pig feed with no negative effect on feed conversion efficiency, carcass and meat quality traits, and may improve shelf life of pork. However, inclusion levels of $7.5 \%$ MOLM may lower FCR. The MOLM inclusion significantly improved the FA composition of the feed, but did not produce the desired improvements in FA composition of meat, probably because of the prominence of fat deposition by de novo lipogenesis in finisher pigs rather than direct incorporation of dietary fatty acids.
\end{abstract}

Keywords: Moringa oleifera, anti-nutrient factors, fatty acid ratios, pork colour, pork odour

\#Corresponding author: vmuchenje@ufh.ac.za

\section{Introduction}

Animal nutrition is a critical component of livestock production not only because the cost of feeding amounts to $60 \%-75 \%$ of total production, but also because nutrition has a major influence on animal growth, health, reproduction and the quality of the products derived from them (Losinger, 1998; Kellems \& Church, 2002; Bhat et al., 2010). The efficiency with which feed consumed by pigs is converted into liveweight gain has a major impact on profitability, and is of great economic importance in pig production 
(Losinger, 1998; Barbut et al., 2008). Feed conversion ratio (FCR) is especially important during the growingfinishing period because $75 \%-80 \%$ of the feed required to attain market weight is consumed during this period.

The composition of feed consumed by pigs has a major influence on the physico-chemical and nutritional quality of pork (Pettigrew \& Esnaola, 2001; Dugan et al., 2004). Fatty acid (FA) composition is an important aspect of meat quality because it influences technological aspects of meat quality (Hugo \& Roodt, 2007) and has implications on human health. While polyunsaturated fatty acids (PUFAs) generally have more health benefits than saturated fatty acids (SFAs), emphasis must be placed on the type of PUFAs consumed, specifically the balance between C18:3n (n-3) and C18:2n (n-6) because the ratio of $n-6: n-3$ is a risk factor for cancers, coronary heart disease and the formation of blood clots, which could lead to a heart attack (Enser, 2001; Wood et al., 2003; Walker et al., 2005). Furthermore, the types of FA present in meat and their susceptibility to oxidation influences the shelf life of meat (Wood et al., 2003). The feed consumed by monogastric animal species has a profound effect on the FA composition of their subcutaneous and intramuscular fat (Troy \& Kerry, 2010).

Research in pig nutrition has shown that the efficiency of feed conversion, quality of pork and FA profiles of meat can be altered by manipulating a pig's diet (Rentfrow et al., 2003; Mas et al., 2010). Moringa oleifera Lam, commonly referred to as the Drumstick tree or Horseradish tree, is a small to medium-sized deciduous tree, originally from India, that now occurs naturally, and is being grown in numerous tropical and sub-tropical regions across the globe (Makkar \& Becker, 1997). Aside from being valued for its hardiness and ability to survive in a wide range of climatic conditions, including drought, $M$. oleifera Lam is esteemed for its nutritional, phenolic, antioxidant and medicinal properties (Makkar \& Becker, 1997; Foidl et al., 2001). Most parts of the plant (leaves, pods, roots) are edible, and can be consumed for their nutritive and medicinal values. Research has shown that fresh $M$. oleifera Lam leaves and dried leaf meal contain high levels of crude protein, vitamins, amino acids, minerals and FAs, including notably high levels of $n$-3 FAs (Makkar \& Becker, 1997; Moyo et al., 2011). Moringa oleifera is used as an indigenous medicine in South Asia and parts of Africa for various ailments (Verma et al., 2009) and its consumption has been reported to improve nutrition, increase immune response, strengthen immune functions and promote health, owing to its high content of micronutrients and phenolics (Yang et al., 2006). In addition to its nutritional potential to promote animal productivity and favourably affect fat composition, its high phenolic content and potent antioxidant properties (Verma et al., 2009) have been shown to have a positive effect on meat quality and oxidative stability (Moyo et al., 2012; Qwele et al., 2013). High phenolic content, on the other hand, affects nutrient availability negatively (Afuang et al., 2003; Ritcher et al., 2003; Olugbemi et al., 2010). Moringa oleifera leaves have been reported to contain $12 \mathrm{~g}$ tannins/kg, which has been described as a negligible amount (Makkar \& Becker, 1997). Studies have been conducted to assess the functional value of feeding M. oleifera leaf meal to various animal species, including cattle (Reyes-Sánchez et al., 2006; Mendieta-Araica et al., 2011), goats (Moyo et al., 2012; Qwele et al., 2013), chickens (Olugbemi et al., 2010; Wapi et al., 2013; Nkukwana et al., 2014a; b; c) and fish (Afuang et al., 2003; Ritcher et al., 2003). However, documented information on the dietary use of $M$. oleifera for pigs is lacking. Species differences, particularly regarding fat deposition and feed conversion efficiency as affected by phenolic compounds in feed warrants further species-specific study. The aim of the present study was to determine the effect that the inclusion of different levels of $M$. oleifera leaf meal (MOLM) in finisher pig feed would have on feed conversion efficiency, physico-chemical quality, shelf life and FA composition of pork.

\section{Materials and Methods}

Animals were managed according to the University of Fort Hare's ethical requirements (Ethical Clearance Certificate Reference Number MAP011 SMUK01). The pigs were housed individually in a smallscale commercial piggery at Fort Cox College of Agriculture and Forestry $\left(32.46{ }^{\circ} \mathrm{S}, 27.01{ }^{\circ} \mathrm{E}\right)$. Pens (3 x 2 $\mathrm{m}$ ) had slanted concrete floors and were each equipped with a concrete feeding trough and a nipple drinker. Twenty-four Large White $x$ Landrace finisher gilts at 14 weeks old and initially weighing $71.6 \mathrm{~kg}$ on average were used in a completely randomised design with six replications per dietary treatment. The pigs were allocated to one of four iso-nitrogenous and iso-energetic (140 g crude protein $/ \mathrm{kg} ; 9.90 \mathrm{MJ}$ net energy/kg) dietary treatments formulated to contain 0\% (T1), 2.5\% (T2), 5\% (T3) and 7.5\% (T4) of MOLM. The M. oleifera was grown commercially by Moringa South Africa, and processed by air drying fresh leaves under shade, after which they were ground into leaf meal through a $2 \mathrm{~mm}$ sieve. The ingredient composition and analysed proximate composition of the dietary treatments are shown in Tables 1 and 2, respectively. The pigs were allowed seven days to adjust to the experimental diets before the trial, lasting six weeks, commenced. They had ad libitum access to feed and unrestricted access to water throughout the trial, which ran until the pigs were 20 weeks old. 
The amount of feed offered to each pig and the amount left over the next morning were weighed daily to determine the average daily feed intake (ADFI). The pigs were weighed weekly to monitor their rate of gain and to determine the average daily gain (ADG) for each animal. Thereafter, the FCR was determined, as a measure of the quantity of feed required to attain a unit of weight gain. Upon completion of the feeding trial, the pigs were fasted for 12 hours prior to slaughter and then weighed prior to transportation to obtain slaughter weights.

Table 1 Composition of dietary treatments on as-fed basis

\begin{tabular}{|c|c|c|c|c|}
\hline \multirow{2}{*}{ Item } & \multicolumn{4}{|c|}{ MOLM* Inclusion level (\%) } \\
\hline & $\mathrm{T} 1(0)$ & T2 (2.5) & T3 (5.0) & T4 (7.5) \\
\hline \multicolumn{5}{|l|}{ Feed ingredients (g/kg) } \\
\hline Yellow maize & 630.8 & 631.6 & 635.7 & 639.8 \\
\hline Wheat bran & 149.3 & 125.8 & 95.5 & 65.7 \\
\hline Soya Hi Pro & 114.2 & 114.2 & 115.1 & 116.1 \\
\hline Sunflower oilcake & 75.0 & 75.0 & 75.0 & 75.0 \\
\hline Limestone powder & 13.35 & 11.10 & 10.95 & 10.80 \\
\hline Monocalcium phosphate & 0.00 & 0.04 & 0.32 & 0.61 \\
\hline Fine salt & 4.86 & 4.82 & 4.79 & 4.76 \\
\hline Methionine & 1.36 & 1.30 & 1.25 & 1.21 \\
\hline Biolysine & 5.90 & 5.90 & 5.90 & 5.90 \\
\hline Tryptophan & 0.15 & 0.17 & 0.19 & 0.22 \\
\hline Threonine & 0.72 & 0.66 & 0.60 & 0.54 \\
\hline Choline chloride & 0.58 & 0.58 & 0.58 & 0.58 \\
\hline Vitamin/mineral premix** & 3.00 & 3.00 & 3.00 & 3.00 \\
\hline Formi ${ }^{\star \star \star}$ & 0.83 & 0.83 & 0.83 & 0.83 \\
\hline \multicolumn{5}{|l|}{ Calculated nutrient levels } \\
\hline Crude protein (g/kg) & 140 & 140 & 140 & 140 \\
\hline Net energy $(\mathrm{MJ} / \mathrm{kg})$ & 9.9 & 9.9 & 9.9 & 9.9 \\
\hline Available lysine (g/kg) & 11.5 & 11.5 & 11.5 & 11.5 \\
\hline Calcium (g/kg) & 7.0 & 7.0 & 7.0 & 7.0 \\
\hline Total phosphorus (g/kg) & 4.7 & 4.7 & 4.7 & 4.7 \\
\hline Fat $(g / k g)$ & 30.9 & 30.9 & 30.9 & 30.9 \\
\hline Calcium (g/kg) & 4.9 & 6.1 & 6.4 & 6.9 \\
\hline Available phosphorus (g/kg) & 3.4 & 3.6 & 3.7 & 3.9 \\
\hline
\end{tabular}

MOLM: Moringa oleifera leaf meal. *MOLM contained $92.0 \mathrm{~g}$ moisture $/ \mathrm{kg} ; 244.7 \mathrm{~g}$ crude protein $/ \mathrm{kg} ; 102.7 \mathrm{~g}$ $\mathrm{ash} / \mathrm{kg} ; 49.3 \mathrm{~g}$ crude fat $/ \mathrm{kg} ; 103.8 \mathrm{~g}$ crude fibre $/ \mathrm{kg} ; 17.4 \mathrm{~g}$ calcium $/ \mathrm{kg} ; 3.4 \mathrm{~g}$ phosphorus $/ \mathrm{kg}$.

** Supplied per kg feed: $3300 \mathrm{IU}$ vitamin $\mathrm{A} ; 330 \mathrm{IU}$ vitamin $\mathrm{D}_{3} ; 19.8 \mathrm{IU}$ vitamin $\mathrm{E} ; 1.32$ vitamin $\mathrm{K} ; 0.05 \mathrm{mg}$ biotin; $0.14 \mathrm{mg}$ folic acid; $4.4 \mathrm{mg}$ niacin; $1 \mathrm{mg}$ pantothenic acid; $0.0132 \mathrm{mg}$ vitamin $B_{12} ; 12.4 \mathrm{mg}$ zinc; $25 \mathrm{mg}$ iron; $5.2 \mathrm{mg}$ manganese; $2.6 \mathrm{mg}$ copper; $0.05 \mathrm{mg}$ selenium.

${ }^{* *}$ Contained $98 \mathrm{~g} / \mathrm{kg}$ potassium diformate, $1.5 \mathrm{~g} / \mathrm{kg}$ silicate.

The pigs were transported during the evening over $70 \mathrm{~km}$ to a small commercial abattoir, where they remained in a lairage with access to drinking water until the next morning, when they were slaughtered. The pigs were stunned prior to slaughter, by placing the electrode tongs behind each ear for $3-4$ seconds, releasing $340 \mathrm{~V}$ of electricity and rendering the pig unconscious before the vena cava was severed by thoracic sticking. After stunning and sticking, each pig was hoisted by a chain around its right ankle and allowed to bleed for five minutes, after which it was placed into a scalding tank of hot water at $65^{\circ} \mathrm{C}$ for three minutes to loosen the hair for easy removal. After scalding, the hair was scraped off each carcass with sharp 
knives. Each carcass was singed with a gas flame after scraping to remove remaining hair, tighten the skin and sterilise the carcass. Each carcass was then eviscerated and the offal inspected for pathology.

After carcasses were split, measurement of back-fat thickness was done between the second- and third-last ribs, $45 \mathrm{~mm}$ from the dorsal midline, using a calliper. $\mathrm{pH}$ measurements were taken 45 minutes $\left(\mathrm{pH}_{45 \mathrm{mins}}\right)$ post mortem in the $\mathrm{m}$. longissimus thoracis et lumborum muscle on the right side of the carcass using a portable $\mathrm{pH}$ meter equipped with an electrode probe and thermometer (Crison $\mathrm{pH} 25$, Crison Instruments, SA, Alella, Spain). Standard solutions of $\mathrm{pH}_{4}$ and $\mathrm{pH}_{7}$ were used to calibrate the meter. Carcasses were chilled at $2{ }^{\circ} \mathrm{C}$ in a cold room. The ultimate $\mathrm{pH}\left(\mathrm{pH}_{24 \mathrm{~h}}\right)$ was taken 24 hours post mortem in the $m$. longissimus thoracis et lumborum muscle on the right side of each carcass. Thereafter, cold carcass weight of each carcass was measured. The $m$. longissimus thoracis et lumborum muscle from the right side of each carcass was cut into $25 \mathrm{~mm}$ thick loin chops. Samples that were not to be analysed the same day were vacuum sealed (Gastrovac Pro, Henkovac, Netherlands) and stored at $-20^{\circ} \mathrm{C}$ until analysis.

Instrumental colour measurements were taken 24 hours post mortem on the exposed cut surface of a $m$. longissimus thoracis et lumborum chop from each carcass using a Minolta colour guide 45/0 BYKGardener $\mathrm{GmbH}$ machine with a $20 \mathrm{~mm}$ diameter measurement area, illuminant D65-day light and $10^{\circ}$ standard observer. The CIE colour coordinates for $L^{*}$, indicating lightness $(0=$ dark, $100=$ light $)$; $a^{*}$, indicating redness (red-green spectrum) and $\mathrm{b}^{*}$, indicating yellowness (yellow-blue spectrum) were measured (CIE, 1976). On each sample, three readings were taken on the surface of the meat, avoiding areas with connective tissue and intramuscular fat, by rotating the colour guide $90^{\circ}$ between measurements to obtain a representative average value. The colour guide was calibrated before measurements using the green standard.

A frozen $m$. longissimus thoracis et lumborum meat sample from each carcass was weighed (Wt 1$)$ and left to thaw at room temperature for 12 hours, after which each sample was weighed again (Wt 2). The thawing loss percentage (TL \%) was then calculated as:

$\mathrm{TL} \%=[(\mathrm{Wt} 1-\mathrm{Wt} 2) / \mathrm{Wt} 1] \times 100$.

The same meat samples, each individually sealed in a watertight PVC plastic bag, were then boiled in a water bath for 45 minutes at $85^{\circ} \mathrm{C}$, after which they were weighed a third time (Wt 3), and the cooking loss percentage (CL\%) was calculated as:

$\mathrm{CL} \%=[(\mathrm{Wt} 2-\mathrm{Wt} 3) / \mathrm{Wt} 2] \times 100$.

For Warner Bratzler Shear Force determination, meat samples were cooked as described above, after which three sub-samples, each measuring $3 \times 1.5 \times 1.5 \mathrm{~cm}$, were taken from each cooked meat sample. Each sub-sample was sheared in a direction perpendicular to that of the muscle fibres using an Instron 3344 Universal Testing Machine (Advanced Laboratory Solutions, USA) equipped with a Warner Bratzler Shear Force (WBSF) apparatus (crosshead speed at $400 \mathrm{~mm} / \mathrm{min}$ ).

A $m$. longissimus thoracis et lumborum muscle sample (loin chop) from each carcass $(n=24)$ was placed on a polystyrene tray and overwrapped with oxygen-permeable plastic film and refrigerated at $3 \pm 1$ ${ }^{\circ} \mathrm{C}$ for 10 days. Instrumental colour measurements $\left(L^{*}, a^{*}, b^{*}\right)$ and sensory appraisal of colour and odour were done on each sample on the first day (Day 0) and evaluated again on days 4,7 and 10. The hue angle, which is an indication of the angle at which a vector radiates into the red-yellow quadrant, was calculated as follows: hue angle $=\tan ^{-1}\left(b^{\star}\right) /\left(a^{*}\right)$; and chroma, which is a measure of colour saturation, was calculated as follows: chroma $=\left(a^{\star^{2}}+b^{*^{2}}\right)^{1 / 2}$ (Minolta, 1993). Sensory appraisal of colour and odour was done by a trained panel of six staff and students from the Department of Livestock and Pasture Science of the University of Fort Hare and from Fort Cox College of Agriculture and Forestry, according to the methods described by Gómez \& Lorenzo (2012) using a nine-point scale (ranging from extremely acceptable to extremely unacceptable (1: extremely unacceptable; 2 : very much unacceptable; 3 : moderately unacceptable; $4=$ slightly unacceptable; 5: between acceptable and unacceptable; 6: slightly acceptable; 7: moderately acceptable; 8: very much acceptable; 9: extremely acceptable).

Total lipids from muscle and subcutaneous fat samples were quantitatively extracted using chloroform and methanol (in a ratio of $2: 1$ ) according to Folch et al.'s (1957) method. The antioxidant butylatedhydroxytoluene was added at a concentration of $0.001 \%$ to the chloroform : methanol mixture. A rotary evaporator was used to dry the fat extracts under vacuum, and the extracts were dried overnight in a vacuum oven at $50{ }^{\circ} \mathrm{C}$, using phosphorus pentoxide as a moisture adsorbent. Total extractable fat was determined gravimetrically from the extracted fat, and expressed as percentage fat (w/w) per $100 \mathrm{~g}$ tissue. The total lipid from samples of the formulated dietary treatments was extracted using Soxhlet extraction according to AOAC (2003) procedures to determine fats. The extracted fat from feed, subcutaneous fat and muscle were stored in a polytop (glass vial, with push-in top) under a blanket of nitrogen and frozen at $-20^{\circ} \mathrm{C}$ pending FA analyses.

A lipid aliquot $(20 \mathrm{mg})$ of feed, subcutaneous and muscle lipid was transferred into a Teflon-lined screw-top test tube with a disposable glass Pasteur pipette. FAs were transesterified to form methyl esters 
using $0.5 \mathrm{~N} \mathrm{NaOH}$ in methanol and $14 \%$ boron trifluoride in methanol (Park \& Goins, 1994). FA methyl esters (FAMEs) from subcutaneous fat, feed and muscle were quantified using a Varian 430 flame ionization GC, with a fused silica capillary column, Chrompack CPSIL $88(100 \mathrm{~m}$ length, $0.25 \mathrm{~mm}$ ID, $0.2 \mu \mathrm{m}$ film thicknesses). Analysis was performed using an initial isothermic period ( $40^{\circ} \mathrm{C}$ for 2 minutes). Thereafter, temperature was increased at a rate of $4{ }^{\circ} \mathrm{C}$ /minute to $230{ }^{\circ} \mathrm{C}$. Finally, an isothermic period at $230{ }^{\circ} \mathrm{C}$ followed for 10 minutes. FAMEs n-hexane $(1 \mu \mathrm{L})$ was injected into the column using a Varian CP 8400 Autosampler. The injection port and detector were maintained at $250{ }^{\circ} \mathrm{C}$. Hydrogen, at $45 \mathrm{psi}$, functioned as the carrier gas, while nitrogen was employed as the make-up gas. Galaxy chromatography software recorded the chromatograms.

FAME samples were identified by comparing the retention times of FAME peaks from samples with those of standards obtained from Supelco (Supelco 37 Component Fame Mix 47885-U, Sigma-Aldrich Aston Manor, Pretoria, South Africa). All other reagents and solvents were of analytical grade and obtained from Merck Chemicals (Pty Ltd, Halfway House, Johannesburg, South Africa). FAs were expressed as the proportion of each FA to the total of FAs present in the sample. The following FA combinations were calculated: omega-3 ( $n-3)$ FAs, omega-6 ( $n$-6) FAs, total saturated fatty acids (SFA), total monounsaturated fatty acids (MUFA), polyunsaturated fatty acids (PUFA), PUFA/SFA ratio (P/S) and $n-6: n-3$ ratio.

From the data of FA composition, the index of atherogenicity (Al) and the index of thrombogenicity (IT) were calculated. The Al is an indication of the relationship between the pro-atherogenic SFAs and the main classes of anti-atherogenic PUFAs and the IT is an indication of the tendency of clot formation in blood vessels, based on the relationship between pro-thrombogenetic SFAs and anti-thrombogenetic MUFAs and PUFAs (Garaffo et al., 2011). The indices were calculated using the formulae proposed by Ulbricht \& Southgate (1991):

$\mathrm{Al}=12: 0+(4 \times 14: 0)+16: 0 /(n-6$ PUFA $+n-3$ PUFA + MUFA $)$

$\mathrm{IT}=14: 0+16: 0+18: 0 /(0.5$ MUFA $)+(0.5 n-6$ PUFA $)+(3 n-3$ PUFA $)+(n-3$ PUFA $n-6$ PUFA $)$

Data for feed conversion efficiency, carcass characteristics, meat quality, shelf life and FA composition were analysed using PROC GLM procedures of SAS (2003) and pairwise comparisons of least square means were done. Data for shelf life parameters was analysed separately using the PROC GLM procedures of SAS (2003) as a repeated measure. Differences were considered different at $P<0.05$ and the statistical model was: $Y_{i j=} \mu+T_{i}+e_{i j}$; where $Y_{i j k}$ represents the dependent variables, $\mu$ represents the overall mean, $T_{i}$ represents the effect of diet and $e_{i j}$ is the random error.

\section{Results}

The effects of dietary treatment on feed conversion parameters and carcass characteristics of the pigs are presented in Table 2. There was no significant difference in the ADG between treatments. However, there was a difference $(P<0.05)$ in the ADFI of the pigs between treatments, with T4 pigs (fed $7.5 \%$ MOLM) consuming a higher amount of feed on a daily basis than the pigs fed the T1, T2 and T3 dietary treatments. The ADFI of T2 and T3 pigs did not significantly differ from the ADFI of pigs fed the control diet. The inclusion of MOLM in feed did not significantly affect the average slaughter weight achieved across treatments. No significant differences were observed for any of the carcass characteristics (backfat thickness, $\mathrm{pH}_{45 \mathrm{mins}}$ ) measured across treatments.

The effects of the inclusion of the various levels of MOLM in feed on physico-chemical meat quality traits are shown in Table 3. There were no significant differences in the $\mathrm{pH}_{24 h}, \mathrm{~L}^{*}, \mathrm{a}^{*}, \mathrm{~b}^{*}, \mathrm{TL} \%, \mathrm{CL} \%$ and WBSF values between treatments. Results on the appraisal of sensory colour and odour during the 10-day shelf life trial are presented in Figures 1 and 2. Differences in colour and odour were observed on day 7, with samples from T3 and T4 having higher $(P<0.05)$ scores than samples from T1 and T2 for colour; and with T2, T3 and T4 having higher $(P<0.05)$ scores than T1 for odour.

The results of the $L^{*}, a^{*}, b^{*}$ measurements taken on days $0,4,7$ and 10 and calculated hue and chroma values are presented in Table 4 . On day 4 , the highest $(P<0.05) \mathrm{b}^{*}$ value was recorded on T2 samples. The highest $(P<0.05)$ hue value was calculated for T4 samples on Day 0 and the lowest $(P<0.05)$ chroma values were calculated on T3 samples on day 7 .

There were no significant differences in the FA composition of the subcutaneous fat (SCF) across samples from the various dietary treatments. The FA composition of meat samples expressed as percentages of the total FA content, is presented in Table 5. The inclusion of MOLM resulted in a difference $(P<0.05)$ in the $\mathrm{C} 18: 0$ (stearic acid) content between samples from pigs fed on the T1 diet and the samples from pigs fed on T2, T3, and T4 diets. 
Table 2 Effect of dietary treatment on growth performance and carcass characteristics (least square mean \pm standard error)

\begin{tabular}{|c|c|c|c|c|c|}
\hline \multirow[b]{2}{*}{ Parameter } & \multicolumn{4}{|c|}{ Dietary treatment (MOLM* Inclusion level, \%) } & \multirow[b]{2}{*}{ Significance } \\
\hline & $\begin{array}{l}\text { T1 (0) } \\
(\mathrm{n}=6)\end{array}$ & $\begin{array}{c}\text { T2 (2.5) } \\
(\mathrm{n}=6)\end{array}$ & $\begin{array}{c}\text { T3 (5.0) } \\
(\mathrm{n}=6)\end{array}$ & $\begin{array}{c}\text { T4 (7.5) } \\
(\mathrm{n}=6)\end{array}$ & \\
\hline \multicolumn{6}{|c|}{ Growth performance } \\
\hline Initial weight & $72.2 \pm 4.23$ & $71.7 \pm 3.62$ & $71.2 \pm 3.62$ & $71.4 \pm 3.62$ & NS \\
\hline ADFI (kg) & $3.1^{\mathrm{a}} \pm 0.07$ & $3.1^{\mathrm{a}} \pm 0.067$ & $3.1^{\mathrm{a}} \pm 0.07$ & $3.6^{\mathrm{b}} \pm 0.07$ & * \\
\hline $\mathrm{ADG}(\mathrm{kg})$ & $0.9 \pm 0.02$ & $0.9 \pm 0.02$ & $1.0 \pm 0.02$ & $0.9 \pm 0.02$ & NS \\
\hline $\mathrm{FCR}$ & $3.3^{b} \pm 0.05$ & $3.4^{b} \pm 0.05$ & $3.2^{\mathrm{a}} \pm 0.05$ & $3.9^{c} \pm 0.05$ & * \\
\hline SW (kg) & $105.3 \pm 6.29$ & $101.8 \pm 5.63$ & $99.2 \pm 5.63$ & $95.6 \pm 5.63$ & NS \\
\hline \multicolumn{6}{|c|}{ Carcass characteristics } \\
\hline $\mathrm{pH}_{45 \min }$ & $6.1 \pm 0.13$ & $6.1 \pm 0.12$ & $6.1 \pm 0.12$ & $5.9 \pm 0.12$ & NS \\
\hline $\mathrm{BFT}(\mathrm{cm})$ & $2.9 \pm 0.27$ & $2.8 \pm 0.24$ & $2.7 \pm 0.24$ & $2.7 \pm 0.24$ & NS \\
\hline
\end{tabular}

${ }^{\text {ab }}$ Means in the same row with different superscripts differ significantly $(P<0.05)$; NS: not significant $(P>0.05)$. * MOLM: Moringa oleifera leaf meal.

ADFI: average daily feed intake; ADG: average daily gain; FCR: feed conversion ratio; SW: slaughter weight; NFT: back fat thickness.

Table 3 Effect of dietary treatment on physico-chemical meat quality traits (least square mean \pm standard error)

\begin{tabular}{lccccc}
\hline \multirow{2}{*}{ Parameter } & \multicolumn{3}{c}{ Dietary treatment (MOLM* inclusion level, \%) } & Significance \\
\cline { 2 - 5 } & $\begin{array}{c}\text { T1 (0) } \\
(\mathbf{n}=\mathbf{6})\end{array}$ & $\begin{array}{c}\text { T2 (2.5) } \\
(\mathbf{n}=\mathbf{6})\end{array}$ & $\begin{array}{c}\text { T3 (5.0) } \\
(\mathbf{n}=\mathbf{6})\end{array}$ & $\begin{array}{c}\text { T4 (7.5) } \\
(\mathbf{n}=\mathbf{6})\end{array}$ & \\
\hline $\mathrm{pH}_{24 \mathrm{~h}}$ & $5.77 \pm 0.066$ & $5.67 \pm 0.075$ & $5.64 \pm 0.066$ & $5.65 \pm 0.066$ & NS \\
$\mathrm{L}^{*}$ & $52.0 \pm 2.19$ & $52.2 \pm 2.49$ & $48.1 \pm 2.18$ & $52.0 \pm 2.19$ & NS \\
$\mathrm{a}^{*}$ & $5.31 \pm 0.499$ & $4.57 \pm 0.568$ & $4.92 \pm 0.497$ & $4.46 \pm 0.499$ & NS \\
$\mathrm{b}^{*}$ & $8.99 \pm 0.701$ & $9.34 \pm 0.798$ & $7.66 \pm 0.699$ & $8.38 \pm 0.701$ & NS \\
$\mathrm{TL}(\%)$ & $1.13 \pm 0.399$ & $1.52 \pm 0.356$ & $1.35 \pm 0.356$ & $2.15 \pm 0.356$ & NS \\
$\mathrm{CL}(\%)$ & $21.9 \pm 0.82$ & $20.9 \pm 0.74$ & $22.3 \pm 0.74$ & $21.5 \pm 0.74$ & NS \\
WBSF & $29.0 \pm 2.91$ & $31.9 \pm 3.32$ & $27.0 \pm 2.90$ & $33.3 \pm 2.91$ & NS \\
\hline
\end{tabular}

* MOLM: Moringa oleifera leaf meal; NS: not significant $(P>0.05)$.

$L^{*}$ : lightness; $a^{*}$ : redness; $b^{\star}$ : yellowness; TL: thawing loss \%; CL: cooking loss; WBSF: Warner Bratzler Shear Force.

The FA ratios of feed and meat samples are presented in Table 6. The total muscle fat was lowest $(P$ $<0.05)$ in samples from T4 pigs. The feed samples from dietary treatments containing higher levels of MOLM had greater $(P<0.05)$ levels of total PUFA, $n-3, n-6$ and better $n-6: n-3$ ratios. However, there were no significant differences in the $n-6: n-3$ ratio of meat samples from different dietary treatments. The average indices of atherogenicity $(\mathrm{T} 1=0.59, \mathrm{~T} 2=0.52, \mathrm{~T} 3=0.57$ and $\mathrm{T} 4=0.57)$ and thrombogenicity $(\mathrm{T} 1=1.35$, $\mathrm{T} 2=1.31, \mathrm{~T} 3=1.26$ and $\mathrm{T} 4=1.26)$ of $\mathrm{LTL}$ muscle samples did not differ significantly $(P>0.05)$. 


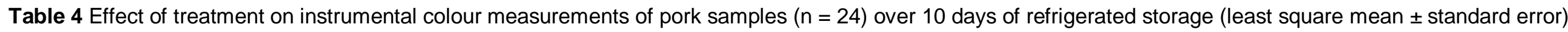

\begin{tabular}{|c|c|c|c|c|c|}
\hline \multirow{2}{*}{ Attribute } & \multirow{2}{*}{ Dietary treatment* } & \multicolumn{4}{|c|}{ Days of storage } \\
\hline & & 0 & 4 & 7 & 10 \\
\hline \multirow[t]{5}{*}{$L^{*}$} & $T 1(n=6)$ & $52.3 \pm 2.33$ & $54.8 \pm 2.33$ & $54.5 \pm 2.33$ & $54.3 \pm 2.24$ \\
\hline & $\mathrm{T} 2(\mathrm{n}=6)$ & $51.5 \pm 2.12$ & $53.9 \pm 2.12$ & $54.9 \pm 2.12$ & $55.0 \pm 2.12$ \\
\hline & T3 $(n=6)$ & $48.1 \pm 2.12$ & $49.6 \pm 2.12$ & $52.0 \pm 2.12$ & $52.4 \pm 2.12$ \\
\hline & $\mathrm{T} 4(\mathrm{n}=6)$ & $51.9 \pm 2.12$ & $52.9 \pm 2.12$ & $54.2 \pm 2.12$ & $54.3 \pm 2.12$ \\
\hline & Significance & NS & NS & NS & NS \\
\hline \multirow[t]{5}{*}{$a^{*}$} & $T 1(n=6)$ & $5.21 \pm 0.598$ & $8.16 \pm 0.598$ & $6.48 \pm 0.598$ & $6.25 \pm 0.598$ \\
\hline & $\mathrm{T} 2(\mathrm{n}=6)$ & $4.95 \pm 0.548$ & $8.96 \pm 0.548$ & $6.77 \pm 0.548$ & $5.05 \pm 0.548$ \\
\hline & T3 $(n=6)$ & $4.90 \pm 0.548$ & $8.62 \pm 0.548$ & $6.95 \pm 0.548$ & $6.09 \pm 0.548$ \\
\hline & $\mathrm{T} 4(\mathrm{n}=6)$ & $4.38 \pm 0.548$ & $8.28 \pm 0.548$ & $6.65 \pm 0.548$ & $5.72 \pm 0.548$ \\
\hline & Significance & NS & NS & NS & NS \\
\hline \multirow[t]{5}{*}{$b^{*}$} & $T 1(n=6)$ & $9.09 \pm 0.710$ & $12.45^{a} \pm 0.710$ & $13.17 \pm 0.710$ & $12.41 \pm 0.710$ \\
\hline & $\mathrm{T} 2(\mathrm{n}=6)$ & $9.16 \pm 0.648$ & $13.15^{b} \pm 0.648$ & $13.25 \pm 0.648$ & $11.47 \pm 0.648$ \\
\hline & T3 $(n=6)$ & $7.64 \pm 0.648$ & $10.86^{a} \pm 0.648$ & $11.96 \pm 0.648$ & $11.16 \pm 0.648$ \\
\hline & $\mathrm{T} 4(\mathrm{n}=6)$ & $8.30 \pm 0.648$ & $12.11^{a} \pm 0.648$ & $12.93 \pm 0.648$ & $11.73 \pm 0.648$ \\
\hline & Significance & NS & * & NS & NS \\
\hline \multirow[t]{5}{*}{ Hue } & $T 1(n=6)$ & $59.5^{a} \pm 2.66$ & $63.1 \pm 2.66$ & $70.6 \pm 2.66$ & $68.7 \pm 2.66$ \\
\hline & $\mathrm{T} 2(\mathrm{n}=6)$ & $61.3^{a} \pm 2.43$ & $62.0 \pm 2.43$ & $70.1 \pm 2.43$ & $73.8 \pm 2.43$ \\
\hline & T3 $(n=6)$ & $57.5^{a} \pm 2.43$ & $57.7 \pm 2.43$ & $66.3 \pm 2.43$ & $68.3 \pm 2.43$ \\
\hline & $\mathrm{T} 4(\mathrm{n}=6)$ & $68.2^{b} \pm 2.43$ & $61.9 \pm 2.43$ & $69.7 \pm 2.43$ & $71.1 \pm 2.43$ \\
\hline & Significance & * & NS & NS & NS \\
\hline \multirow[t]{5}{*}{ Chroma } & T1 $(n=6)$ & $10.55 \pm 0.770$ & $14.90^{a} \pm 0.770$ & $14.74 \pm 0.770$ & $13.96 \pm 0.770$ \\
\hline & $\mathrm{T} 2(\mathrm{n}=6)$ & $10.45 \pm 0.703$ & $15.92^{a} \pm 0.703$ & $14.90 \pm 0.703$ & $12.56 \pm 0.703$ \\
\hline & T3 $(n=6)$ & $9.17 \pm 0.703$ & $13.96^{b} \pm 0.703$ & $13.85 \pm 0.703$ & $12.82 \pm 0.703$ \\
\hline & $\mathrm{T} 4(\mathrm{n}=6)$ & $9.41 \pm 0.703$ & $14.69^{a} \pm 0.703$ & $14.56 \pm 0.703$ & $13.07 \pm 0.703$ \\
\hline & Significance & NS & * & NS & NS \\
\hline
\end{tabular}

* T1: 0\% Moringa oleifera leaf meal (MOLM); T2: 2.5\% MOLM; T3: 5\% MOLM; T4: 7.5\% MOLM.

${ }^{\mathrm{ab}}$ Means in the same column with different superscripts are significantly different $(P<0.05)$; NS: not significant $(P>0.05)$. 


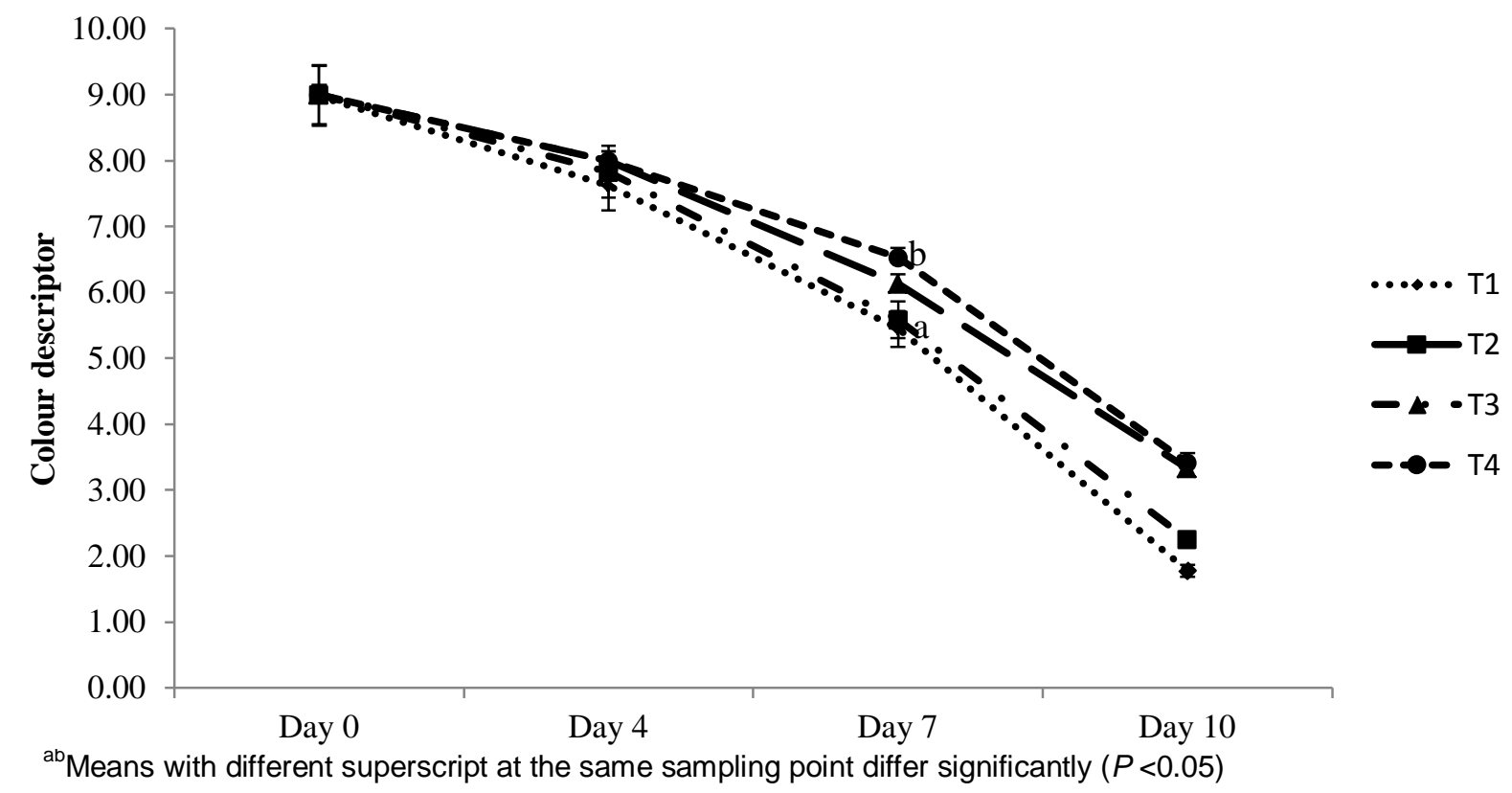

Figure 1 Effect of dietary treatment over time on sensory appraisal of colour of pork samples $(n=24)$ during 10 days of refrigerated storage (1: extremely unacceptable; 2 : very much unacceptable; 3 : moderately unacceptable; 4: slightly unacceptable; 5 : between acceptable and unacceptable; 6 : slightly acceptable; 7: moderately acceptable; 8 : very much acceptable; 9 : extremely acceptable).

T1: 0\% Moringa oleifera leaf meal (MOLM); T2: 2.5\% MOLM; T3: 5\% MOLM; T4: 7.5\% MOLM.

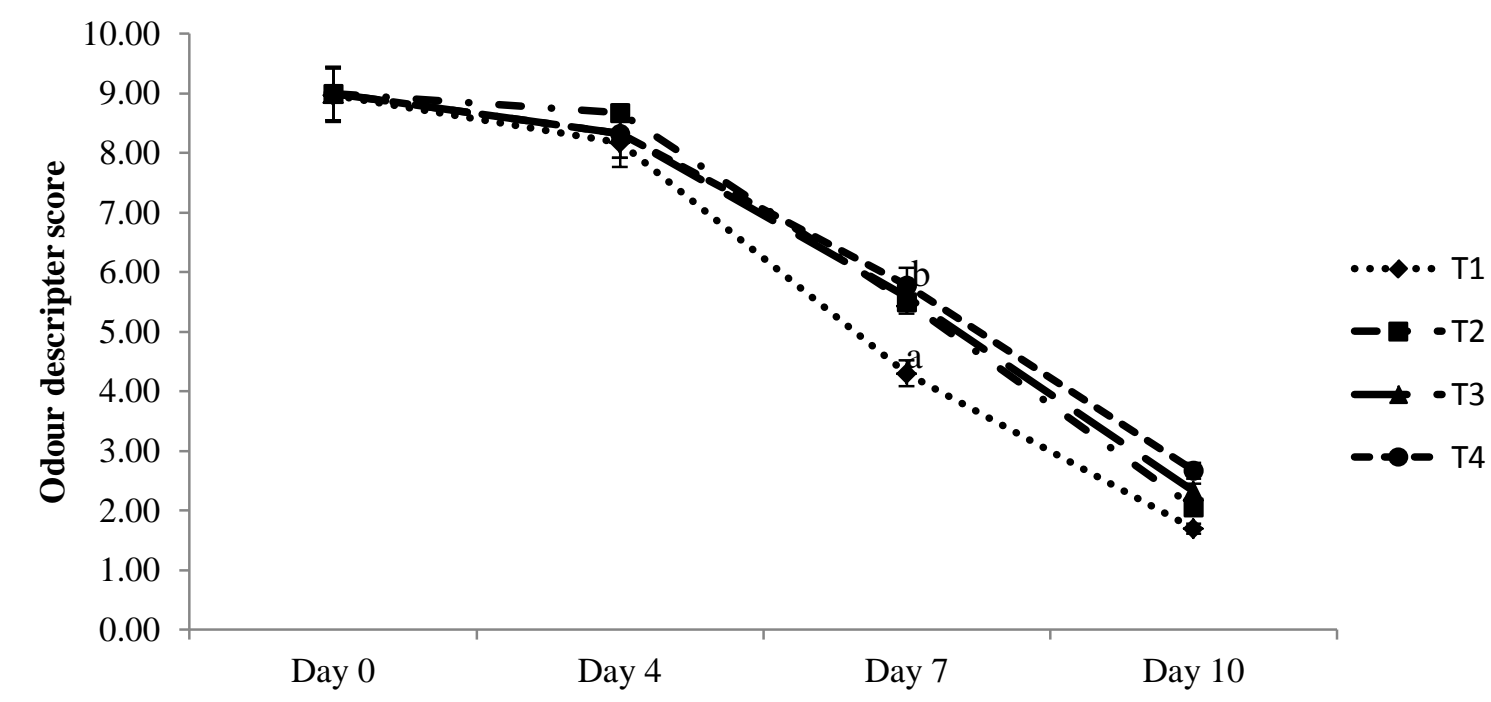

${ }^{\mathrm{ab}}$ Means with different superscript at the same sampling point differ significantly $(P<0.05)$.

Figure 2 Effect of dietary treatment over time on sensory appraisal of odour of pork samples $(n=24)$ during 10 days of refrigerated storage (1: extremely unacceptable; 2 : very much unacceptable; 3 : moderately unacceptable; 4: slightly unacceptable; 5: between acceptable and unacceptable; 6 : slightly acceptable; 7: moderately acceptable; 8: very much acceptable; 9 : extremely acceptable).

T1: 0\% Moringa oleifera leaf meal (MOLM); T2: 2.5\% MOLM; T3: 5\% MOLM; T4: 7.5\% MOLM. 
Table 5 Effect of dietary treatment on total \% fatty acid composition of $m$. longissimus thoracis muscle (least square mean \pm standard error)

\begin{tabular}{|c|c|c|c|c|c|}
\hline \multirow{2}{*}{$\begin{array}{l}\text { Fatty acid (\%) } \\
\text { of } \\
\text { total fatty acids }\end{array}$} & \multicolumn{4}{|c|}{ Dietary treatment (MOLM* inclusion level, \%) } & \multirow{2}{*}{ Significance } \\
\hline & $\begin{array}{c}\text { T1 (0) } \\
(n=6)\end{array}$ & $\begin{array}{c}\text { T2 (2.5) } \\
(\mathrm{n}=6)\end{array}$ & $\begin{array}{c}\text { T3 (5.0) } \\
(\mathrm{n}=6)\end{array}$ & $\begin{array}{c}\text { T4 (7.5) } \\
(\mathrm{n}=6)\end{array}$ & \\
\hline $\mathrm{C} 12: 0$ & $0.01 \pm 0.006$ & $0.01 \pm 0.006$ & $0.01 \pm 0.006$ & $0.01 \pm 0.006$ & NS \\
\hline C14:0 & $1.53 \pm 0.090$ & $1.63 \pm 0.082$ & $1.53 \pm 0.082$ & $1.52 \pm 0.082$ & NS \\
\hline C16:0 & $27.82 \pm 0.286$ & $28.3 \pm 0.26$ & $27.57 \pm 0.26$ & $27.66 \pm 0.26$ & NS \\
\hline C17:0 & $0.17 \pm 0.017$ & $0.16 \pm 0.016$ & $0.16 \pm 0.016$ & $0.16 \pm 0.016$ & NS \\
\hline C18:0 & $12.76^{\mathrm{b}} \pm 0.371$ & $11.59^{\mathrm{a}} \pm 0.337$ & $11.61^{a} \pm 0.337$ & $11.46^{\mathrm{a}} \pm 0.337$ & * \\
\hline C20:0 & $0.11 \pm 0.007$ & $0.12 \pm 0.006$ & $0.13 \pm 0.006$ & $0.11 \pm 0.006$ & NS \\
\hline $\mathrm{C} 22: 0$ & $0.04 \pm 0.013$ & $0.05 \pm 0.012$ & $0.06 \pm 0.012$ & $0.06 \pm 0.012$ & NS \\
\hline $\mathrm{C} 24: 0$ & ND & $0.04 \pm 0.015$ & $0.05 \pm 0.013$ & $0.07 \pm 0.011$ & NS \\
\hline C16:1c9 & $3.03 \pm 0.232$ & $3.60 \pm 0.211$ & $3.49 \pm 0.211$ & $3.57 \pm 0.211$ & NS \\
\hline C17:1c10 & $0.06 \pm 0.021$ & $0.04 \pm 0.019$ & $0.05 \pm 0.019$ & $0.09 \pm 0.019$ & NS \\
\hline C18:1t9 & $0.04 \pm 0.004$ & $0.05 \pm 0.004$ & $0.04 \pm 0.003$ & $0.05 \pm 0.003$ & NS \\
\hline C18:1c9 & $37.57 \pm 1.727$ & $38.30 \pm 1.545$ & $39.29 \pm 1.545$ & $38.09 \pm 1.545$ & NS \\
\hline C18:1c7 & $3.83 \pm 0.189$ & $4.13 \pm 0.169$ & $4.13 \pm 0.169$ & $4.27 \pm 0.169$ & NS \\
\hline C18:2c9,12(n-6) & $9.83 \pm 1.585$ & $9.04 \pm 1.418$ & $8.76 \pm 1.418$ & $9.40 \pm 1.418$ & NS \\
\hline $\mathrm{C} 18: 3 \mathrm{c} 6,9,12(n-3)$ & $0.05 \pm 0.017$ & $0.05 \pm 0.011$ & $0.05 \pm 0.011$ & $0.05 \pm 0.011$ & NS \\
\hline C18:3c9,12,15(n-3) & $0.77 \pm 0.045$ & $0.79 \pm 0.040$ & $0.84 \pm 0.040$ & $0.81 \pm 0.040$ & NS \\
\hline C20:2c11,14(n-6) & $0.19 \pm 0.022$ & $0.16 \pm 0.020$ & $0.17 \pm 0.022$ & $0.17 \pm 0.020$ & NS \\
\hline $\mathrm{C} 20: 3 \mathrm{c} 11,14,17(n-3)$ & $0.21 \pm 0.042$ & $0.21 \pm 0.038$ & $0.22 \pm 0.038$ & $0.26 \pm 0.038$ & NS \\
\hline $\mathrm{C} 20: 4 \mathrm{c}, 8,11,14(n-6)$ & $0.05 \pm 0.007$ & ND & $0.04 \pm 0.004$ & $0.03 \pm 0.004$ & NS \\
\hline C20:4c5,8,11,14(n-6) & $1.93 \pm 0.367$ & $1.80 \pm 0.333$ & $1.90 \pm 0.333$ & $2.25 \pm 0.333$ & NS \\
\hline
\end{tabular}

* MOLM: Moringa oleifera leaf meal.

${ }^{\mathrm{ab}}$ Means in the same row with different superscripts are significantly different $(P<0.05)$; NS: not significant $(P>0.05)$;

ND: not detected; SFA: saturated fatty acids; MUFA: monounsaturated fatty acids; PUFA: polyunsaturated fatty acids; $n$-6: omega 6 fatty acids; $n$-3: omega 3 fatty acids; IMF: intramuscular fat; DM: dry matter; PUFA : SFA: polyunsaturated fatty acids/saturated fatty acids; $n-6 / n-3$ : omega 6 fatty acids/omega 3 fatty acids.

\section{Discussion}

Pigs that received the diet containing 7.5\% MOLM consumed an average of $428-590 \mathrm{~g}$ more feed daily than their counterparts fed with T1, T2 and T3. Consequently, a significantly higher FCR was recorded for these pigs, implying that they were less efficient at converting feed into body mass gain than the pigs fed on T1, T2 and T3 diets. These results differ from those of Acda et al. (2010), who reported that the partial replacement of commercial pre-starter and starter pig feed with up to $10 \%$ MOLM did not result in significant differences in ADFI. This difference may be because of the vast difference in age of the pigs used in the two studies (pre-starter vs. finisher pigs).

The increase in daily feed intake in pigs fed diets containing higher levels of MOLM may be attributed to a decrease in nutrient availability owing to the presence of phyto-chemicals or anti-nutrient factors (ANFs) (Afuang et al., 2003). While tannin levels were not evaluated in the present study, MOLM from the same source and grown under similar conditions was evaluated by Moyo et al. (2011) and reported to have tannin levels of $32 \mathrm{~g} / \mathrm{kg}$, which is comparatively higher than the $12 \mathrm{~g} / \mathrm{kg}$ reported by Makkar \& Becker (1997). Tannins are reportedly likely to result in a depression in growth rate owing to reduced utilisation in protein and possible damage to the mucosal lining of the digestive track in monogastrics when their levels in feed are $5 \%$ and above. This is consistent with the increases in daily feed intake observed in the present study in pigs consuming the $7.5 \%$ MOLM treatment (T4). The MOLM has also been reported to contain $80 \mathrm{~g} / \mathrm{kg}$ of saponins; which has been described as a substantial amount (Makkar \& Becker, 1997). Saponins are 
Table 6 Effect of Moringa oleifera leaf meal (MOLM) inclusion on fatty acid ratios of feed and $m$. longissimus thoracis muscle samples (least square mean \pm standard error)

\begin{tabular}{|c|c|c|c|c|c|}
\hline \multirow{2}{*}{$\begin{array}{l}\text { Fatty acid \% } \\
\text { of } \\
\text { total fatty acids }\end{array}$} & \multicolumn{4}{|c|}{ Dietary treatment (MOLM inclusion level, \%) } & \multirow{2}{*}{ Significance } \\
\hline & $\mathrm{T} 1(0)$ & T2 (2.5) & T3 (5.0) & $\mathrm{T} 4(7.5)$ & \\
\hline \multicolumn{6}{|l|}{ Feed samples } \\
\hline Total SFA & $16.62^{b} \pm 0.007$ & $16.63^{b} \pm 0.007$ & $16.66^{\mathrm{C}} \pm 0.007$ & $16.43^{\mathrm{a}} \pm 0.007$ & * \\
\hline Total MUFA & $31.5^{c} \pm 0.02$ & $28.5^{\mathrm{a}} \pm 0.02$ & $28.6^{\mathrm{b}} \pm 0.02$ & $28.6^{\mathrm{b}} \pm 0.02$ & * \\
\hline Total PUFA & $51.9^{\mathrm{a}} \pm 0.01$ & $54.9^{c} \pm 0.01$ & $54.8^{\mathrm{b}} \pm 0.01$ & $54.9^{c} \pm 0.01$ & * \\
\hline PUFA:SFA & $3.12^{\mathrm{a}} \pm 0.014$ & $3.30^{b} \pm 0.011$ & $3.29^{b} \pm 0.011$ & $3.33^{\mathrm{c}} \pm 0.011$ & * \\
\hline Total $n-6$ & $50.3^{\mathrm{a}} \pm 0.16$ & $52.6^{\mathrm{c}} \pm 0.15$ & $51.8 \pm 0.152$ & $51.7^{\mathrm{b}} \pm 0.15$ & * \\
\hline Total $n-3$ & $1.55^{\mathrm{a}} \pm 0.322$ & $2.38^{\mathrm{b}} \pm 0.231$ & $2.97^{\mathrm{c}} \pm 0.231$ & $3.25^{d} \pm 0.231$ & * \\
\hline$n-6: n-3$ & $35.45^{\mathrm{C}} \pm 1.810$ & $22.08^{b} \pm 1.600$ & $14.24^{\mathrm{a}} \pm 1.600$ & $15.90^{\mathrm{a}} \pm 1.600$ & * \\
\hline Meat samples & $(n=6)$ & $(n=6)$ & $(n=6)$ & $(n=6)$ & \\
\hline Total SFA & $42.4 \pm 0.56$ & $41.9 \pm 0.51$ & $41.1 \pm 0.51$ & $41.0 \pm 0.51$ & NS \\
\hline Total MUFA & $44.5 \pm 1.84$ & $46.1 \pm 1.68$ & $47.0 \pm 1.68$ & $46.0 \pm 1.68$ & NS \\
\hline Total PUFA & $13.10 \pm 1.853$ & $12.04 \pm 1.685$ & $11.92 \pm 1.685$ & $12.95 \pm 1.685$ & NS \\
\hline Total $n-6$ & $12.10 \pm 1.808$ & $10.99 \pm 1.644$ & $10.82 \pm 1.644$ & $11.82 \pm 1.644$ & NS \\
\hline Total $n-3$ & $1.00 \pm 0.066$ & $1.04 \pm 0.060$ & $1.11 \pm 0.060$ & $1.12 \pm 0.060$ & NS \\
\hline PUFA:SFA & $0.31 \pm 0.045$ & $0.29 \pm 0.041$ & $0.29 \pm 0.041$ & $0.32 \pm 0.041$ & NS \\
\hline$n-6: n-3$ & $12.07 \pm 1.332$ & $10.09 \pm 1.210$ & $9.59 \pm 1.210$ & $10.61 \pm 1.210$ & NS \\
\hline Total muscle fat & $2.92^{b} \pm 0.387$ & $3.07^{b} \pm 0.352$ & $2.69^{\mathrm{ab}} \pm 0.352$ & $2.00^{\mathrm{a}} \pm 0.352$ & * \\
\hline
\end{tabular}

reportedly characterized by a bitter taste and have been known to reduce palatability of feeds. Published reports on the effect of feeding $m$. oleifera to pigs on carcass characteristics are scarce, but the results obtained in the present study are in line with those of Zanu et al. (2012), who observed that the incorporation of $5 \%, 10 \%$ and $15 \%$ of MOLM into broiler feed did not cause significant differences in the carcass characteristics. Some studies have reported on the nutritional composition and polyphenolic properties of meat from goats fed $m$. oleifera leaves (Moyo et al., 2011; Qwele et al., 2013). The feeding of MOLM caused significant improvements in quality traits such as the colour 24 hours post mortem of goat meat in these studies, contrary to the findings in the current study (Qwele et al., 2013). An explanation for lack of significant differences in physico-chemical meat quality in the present study may be that while nutrition has an influence on physico-chemical meat quality, another major factor responsible for changes in meat quality is the physiological response of the animal to stress during transportation, handling and slaughter (Muchenje et al., 2009; Gajana et al., 2013).

The results indicate that inclusion of MOLM in feed had a significant effect on improving shelf life by prolonging the acceptability of colour and odour during 10 days of refrigerated storage. For instrumental colour measurements, the mean $L^{*}$ values on day 0 (24 h post mortem) of T1 (52.3), T2 (51.5), and T4 (51.9) fell within the range of $51-55$, as reported by Ngapo et al. (2012), although the T3 L* value (48.1) was slightly lower. The greater $b *$ values found with increasing levels of MOLM is in line with the findings of Ritcher et al. (2003), Reyes-Sánchez et al. (2006) and Wapi et al. (2013), and may be attributed to the higher beta-carotene content of these dietary treatments owing to MOLM inclusion. It is unclear why lower $b^{*}$ values were recorded for T3 samples. The higher hue and chroma values in meat samples from MOLM-fed pigs indicate that the colour of these samples was more saturated and intense, and these improvements may be attributed to the presence of the anti-nutrient phyto-chemicals (such as tannins) in $M$. oleifera which reportedly possess colour-stabilizing antioxidative properties (Moyo et al., 2011). This is in agreement with results reported by Wapi et al. (2013), which indicated that broiler chickens fed on MOLM exhibited better colour $\left(L^{*}, a^{*}\right.$ and $\left.b^{\star}\right)$ values during seven days of refrigerated storage. 
Increased inclusion of MOLM in feed caused a reduction in total muscle fat content of pork, which is beneficial from a health perspective. While the C18:0 (stearic acid) content was lower in meat from MOLMfed pigs, it is a health neutral SFA with regards to cardiovascular health, thus lower levels of C18:0 did not necessarily add any health advantage to the meat. In spite of the dietary treatments with MOLM included having significantly higher levels of total $n-6$ and $n-3$ FAs and significantly more favourable $n-6: n-3$ ratios, the meat samples did not differ significantly in these areas. A possible contributing factor may have been the age of the pigs. According to Van Heerden \& Smith (2013), the maturity of animals has an influence on the FA composition of the meat. In pigs, as growth progresses, the amount of energy needed for protein deposition decreases, increasing the amount of energy available for fat deposition (Enser et al., 1996). Consequently, as growth progresses in pigs, the direct incorporation of C18:2n-6 dietary FAs into body tissues decreases and the conversion of excess energy to SFAs and MUFAs fat by de novo lipogenesis increases (Raj et al., 2010). It is likely that inclusion of MOLM in feed for pigs from an earlier age and stage of production will result in a significant incorporation of desirable PUFAs in the meat. In line with this, Enser et al. (2000) reported that inclusion of 4\% $n-3$ rich linseed in pig feed from 25 to $95 \mathrm{~kg}$ liveweight led to a $56 \%$ increase in the $n-3$ content of intramuscular fat. This may suggest that the inclusion of the levels of MOLM in the present study from an earlier age may result in a significant increase in the PUFA of intramuscular fat.

\section{Conclusions}

The results of the present study indicated that inclusion of 2.5\% and 5\% of MOLM in finisher pig feed had no detrimental effects on feed conversion efficiency, carcass characteristics or physico-chemical meat quality, and significantly prolonged the acceptability of pork colour and odour during 10 days of refrigerated storage. However, inclusion of $7.5 \%$ MOLM increased ADFI, resulting in poorer feed conversion efficiency, and this inclusion level is therefore unadvisable. While inclusion of MOLM in finisher pig feed significantly improved the $n-3$ content and $n-6: n-3$ ratio of the feed, these improvements were not reflected in the FA composition of the subcutaneous fat and the meat. This may be attributed to the reduced levels of dietary FA incorporation in favour of SFA and MUFA incorporation from de novo lipogenesis, which becomes more dominant as growth progresses. Hence, inclusion of MOLM in feed from an earlier age and stage of production may have a more profound effect and may be worth investigating.

\section{Acknowledgements}

The authors are grateful to DST-NRF SA-Argentina Research Collaboration for funding this study, and to Govan Mbeki Research and Development Centre and Canon Collins Educational and Legal Assistance Trust for financial assistance. .

\section{References}

Acda, S.P., Musilunga, H.G.D. \& Moog, B.A., 2010. Partial substitution of commercial swine feeds with Malungay (Moringa oleifera) leaf meal under backyard conditions. Philipp. J. Vet. Anim. Sci. 36 (2), 137-146.

Afuang, W., Siddhuraju, P. \& Becker, K., 2003. Comparative nutritional evaluation of raw, methanol extracted residues and methanol extracts of Moringa (Moringa oleifera Lam.) leaves on growth performance and feed utilization in Nile tilapia (Oreochromisniloticus L.). Aquac. 34, 1147-1159.

AOAC, 2003. Official Methods of Analysis,14th ed. Association of Official Analytical Chemists, Washington, DC, USA.

Barbut, S., Sosnicki, A.A., Lonergan, S.M., Knapp, T., Ciobanu, D.C., Gatcliffe, L.J., Huff-Lonergan, E. \& Wilson, E.W., 2008. Progress in reducing the pale, soft and exudative (PSE) problem in pork and poultry meat. Meat Sci. $79,46-63$.

Bhat, P.N., Mohan, N.H. \& Deo, S., 2010. Pig Production, Global Media, Delhi, India.

CIE, 1976. Colorimetry, $2^{\text {nd }}$ ed. Commission International de l'Eclairage, Vienna, Switzerland.

Dugan, M.E.R., Aalus, J.L. \& Utaro, B., 2004. Nutritional manipulation of pork quality: Current opportunities. Adv. Pork Prod. 15, 237-243.

Enser, M., 2001. The role of fats in human nutrition. In: Oils and Fats, Vol. 2. Animal Carcass Fats. Ed: Rossell, B., Leatherhead Publishing, Surrey. pp. 77-122.

Enser, M., Hallet, K, Hewitt, B., Fursey, G.A.J. \& Wood, J.D., 1996. Fatty acid content and composition of English beef, lamb and pork at retail. Meat Sci. 4, 443-456.

Enser, M., Richardson, R.I., Wood, J.D., Gill, B.P. \& Sheard, P.R., 2000. Feeding linseed to increase the $n-3$ PUFA of pork: fatty acid composition of muscle, adipose tissue, liver and sausages. Meat Sci. 55, 201-212. 
Foidl, N., Makkar, H.P.S. \& Becker, K., 2001. The potential of Moringa oleifera for agricultural and industrial uses. In: The Miracle Tree: The Multiple Uses of Moringa. Ed: Fuglie, L.J., CTA, Wageningen. pp. 45-76.

Folch, J., Lees, M. \& Sloane-Stanley, G.H., 1957. A simple method for the isolation and purification of total lipids from animal tissue. J. Biol. Chem. 226, 497-509.

Gajana, C.S., Nkukwana, T.T., Marume, U. \& Muchenje, V., 2013. Effects of transportation time, distance, stocking density, temperature and lairage time on incidences of pale soft exudative (PSE) and the physico-chemical characteristics of pork. Meat Sci. 95, 520-525.

Garaffo, M.A., Vassallo-Agius, R., Nengas, Y., Lembo, E., Rando, R., Maisano, R., Dugo, G. \& Giuffrida, D., 2011. Fatty acids profile, artherogenic (IA) and thrombogenic (IT) health lipid indices, of raw roe of blue fin tuna (Thunnus thynnus L.) and their salted product "bottargo". Food Nutr. Sci. 2, 736-743.

Gómez, M. \& Lorenzo, J.M., 2012. Effect of packaging conditions of shelf-life of fresh foal meat. Meat Sci. $91,513-520$.

Hugo, A. \& Roodt, E., 2007. Significance of porcine fat quality in meat technology: A review. Food Rev. Int. 23, 175-198.

Kellems, R.O. \& Church, D.C., 2002. Livestock Feeds and Feeding. (5th ed.). Prentice Hall, New Jersey, USA.

Losinger, W.C., 1998. Feed conversion ratio of finisher pigs in the USA. Prev. Vet. Med. 36, 287-305.

Mas, G., Llavall, M., Coll, D., Roca, R., Diaz, I., Gispert, M., Oliver, M.A. \& Realini, C.E., 2010. Carcass and meat quality characteristics and fatty acid composition of tissues from Pietrain-crossed barrows and gilts fed an elevated monounsaturated fat diet. Meat Sci. 85, 707-714.

Makkar, H.P.S. \& Becker, K., 1997. Nutrients and anti-quality factors in different morphological parts of the Moringa oleifera tree. J. Agric. Sci. 128 (3), 311-322.

Mendieta-Araica, B., Spörndly, R., Reyes-Sànchez, N. \& Spörndly, E., 2011. Moringa (Moringa oleifera) leaf meal as a source of protein in locally produced concentrates for dairy cows fed low protein diets in tropical areas. Livest. Sci. 137, 10-17.

Minolta, 1993. Precise colour communication. Minolta Camera, Ltd., Ramsey, New Jersey.

Moyo, B., Masika, P.J., Hugo, A. \& Muchenje, V., 2011. Nutritional characterization of Moringa (Moringa oleifera Lam.) leaves. Afr. J. Biotech. 10, 12925-12933.

Moyo, B., Oyedemi, S., Masika, P.J. \& Muchenje, V., 2012. Polyphenolic content and antioxidant properties of Moringa oleifera leaf extracts and enzymatic activity of liver from goats supplemented with Moringa oleifera leaves or sunflower seed cake. Meat Sci. 91, 441-447.

Muchenje, V., Dzama, K., Chimonyo, M., Strydom, P.E. \& Raats, J.G., 2009. Relationship between pre-slaughter stress responsiveness and beef quality in three cattle breeds. Meat Sci. 81, 653-657.

Ngapo, T.M., Riendeau, L., Laberge, C., Le Blanc, D. \& Fortin, J., 2012. "Chilled" pork: Part 1: Sensory and physico-chemical quality. Meat Sci. 92, 330-337.

Nkukwana, T.T., Muchenje, V., Masika, P.J., Hoffman, L.C. \& Dzama, K., 2014a. The effect of Moringa oleifera leaf meal supplementation on tibia strength, morphology and inorganic content of broiler chickens. S. Afr. J. Anim. Sci. 44, 228-239.

Nkukwana, T.T., Muchenje, V., Masika, P.J., Hoffman, L.C., Dzama, K. \& Descalzo, A.M., 2014b. Fatty acid composition and oxidative stability of breast meat from broiler chickens supplemented with Moringa oleifera leaf meal over a period of refrigeration. Food Chem. 142, 255-261.

Nkukwana, T.T., Muchenje, V., Pieterse, E., Masika, P.J., Mabusela, T.P., Hoffman, L.C. \& Dzama, K., 2014c. Effect of Moringa oleifera leaf meal on growth performance, apparent digestibility, digestive organ size and carcass yield in broiler chickens. Livest. Sci. 161, 139-146.

Olugbemi, T.S., Mutayoba, S.K. \& Lekule, F.P., 2010. Effect of Moringa (Moringa oleifera) inclusion in cassava based diets fed to broiler chickens. Int. J. Poult. Sci. 9, 363-367.

Park, P.W. \& Goins, R.E., 1994. In situ preparation of fatty acid methyl esters for analysis of fatty acid composition in foods. J. Food Sci. 59, 1262-1266.

Pettigrew, J.E. \& Esnaola, M.A., 2001. Swine nutrition and pork quality: A review. J. Anim. Sci. 79 (E Supplement), E316-E342.

Qwele, K., Hugo, A., Oyedemi, S.O., Moyo, B., Masika, P.J. \& Muchenje, V., 2013. Chemical composition, fatty acid content and antioxidant potential of meat from goats supplemented with Moringa (Moringa oleifera) leaves, sunflower cake and grass hay. Meat Sci. 93, 455-462.

Raj, St., Skiba, G., Weremko, D., Fandrejewski, H., Migdał, W., Borowiec, F. \& Poławska, E., 2010. The relationship between the chemical composition of the carcass and the fatty acid composition of intramuscular fat and backfat of several pig breeds slaughtered at different weights. Meat Sci. 86, 324-330. 
Rentfrow, G., Sauber, T.E., Allee, G.L. \& Berg, E.P., 2003. The influence of diets containing either conventional corn with choice with grease, high oil corn, or high oil high oleic corn on belly/bacon quality. Meat Sci. 64, 459-466.

Reyes-Sànchez, N., Spörndly, E. \& Ledin, I., 2006. Effect of feeding different levels of foliage of Moringa oleifera to creole dairy cows on intake, digestibility, milk production and composition. Livest. Sci. 101, 24-31.

Ritcher, N., Siddhuraju, P. \& Becker, K., 2003. Evaluation of nutritional quality of moringa (Moringa oleifera Lam.) leaves as an alternative protein source for Nile tilapia (Oreochromis niloticus L.). Aquac. 217, 599-611.

SAS, 2003. SAS User's Guide: Statistics, Version 9.1 ed. SAS Institute, Cary, NC. www.sas.com

Troy, D.J. \& Kerry, J.P., 2010. Consumer perception and the role of science in the meat industry. Meat Sci. 86, 214-226.

Ulbricht, T.L.V. \& Southgate, D.A.T., 1991. Coronary heart disease: Seven dietary factors. Lancet 338, 985-992.

Van Heerden, S.M. \& Smith, M.F., 2013. The nutrient composition of three cuts obtained from P-class South African pork carcasses. Food Chem. 140, 458-465.

Verma, A.R., Vijayakumar, M., Mathela, C.S. \& Rao, C.V., 2009. In vitro and in vivo antioxidant properties of different fractions of Moringa oleifera leaves. Food Chem. Toxicol. 47, 2196-2201.

Walker, P., Rhubart-Berg, P., McKenzie, S., Kelling, K. \& Lawrence, R.S., 2005. Public health implications of meat production and consumption. Public Health Nutr. 8 (4), 348-356.

Wapi, C., Nkukwana, T.T., Hoffman, L.C., Dzama, K., Pieterse, E., Mabusela, T. \& Muchenje, V., 2013. Physico-chemical shelf-life indicators of meat from broilers given Moringa oleifera leaf meal. S. Afr. J. Anim. Sci. 43 (Supp. 1), 43-47.

Wood, J.D., Richardson, R.I., Nute, G.R., Fisher, A.V., Campo, M.M., Kasapidou, E., Sheard, P.R. \& Enser, M., 2003. Effects of fatty acids on meat quality: A review. Meat Sci. 66, 21-32.

Yang, R., Chang, L., Hsu, J., Weng, B.C., Palada, M.C., Chadha, M.L. \& Levasseur, V., 2006. Nutritional and functional properties of Moringa leaves - from germplasm, to plant, to food, to health. In: Moringa and other highly nutritious plant resources: Strategies, standards and markets fora better impact on nutrition in Africa. http://miracletrees.org/moringa-doc/from-germplasm-to-plant-to-food-to-health.pdf

Zanu, H.K., Asiedu, P., Tampuori, M., Abada, M. \& Asante, I., 2012. Possibilities of using Moringa (Moringa oleifera) leaf meal as a partial substitute for fishmeal in broiler chickens diets. Online J. Anim. Feed Res. 2 (1), 70-75. 